\title{
Correction to: La respuesta de Quevedo al padre Pineda: una obra posiblemente censurada
}

\author{
María José Alonso Veloso ${ }^{1}$
}

Published online: 19 June 2019

(c) The Author(s) 2019

\section{Correction to: Neophilologus https://doi.org/10.1007/s11061-019-09610-z}

The article La respuesta de Quevedo al padre Pineda: una obra posiblemente censurada, written by María José Alonso Veloso, was originally published electronically on the publisher's internet portal (currently SpringerLink) on 24 April 2019 without open access.

With the author(s)' decision to opt for Open Choice, the copyright of the article changed on 18 June 2019 to (C) The Author(s) 2019 and the article is forthwith distributed under the terms of the Creative Commons Attribution 4.0 International License (http://creativecommons.org/licenses/by/4.0/), which permits use, duplication, adaptation, distribution and reproduction in any medium or format, as long as you give appropriate credit to the original author(s) and the source, provide a link to the Creative Commons license and indicate if changes were made. The original article has been corrected.

Publisher's Note Springer Nature remains neutral with regard to jurisdictional claims in published maps and institutional affiliations.

Open Access This article is distributed under the terms of the Creative Commons Attribution 4.0 International License (http://creativecommons.org/licenses/by/4.0/), which permits unrestricted use, distribution, and reproduction in any medium, provided you give appropriate credit to the original author(s) and the source, provide a link to the Creative Commons license, and indicate if changes were made.

The original article can be found online at https://doi.org/10.1007/s11061-019-09610-z.

María José Alonso Veloso

mariajose.alonso@usc.es

http://www.usc.es/gl/investigacion/grupos/quevedo

http://mariajosealonso.wix.com/transmision-quevedo

1 Departamento de Lengua y Literatura Españolas, Teoría de la Literatura y Lingüística General. Facultad de Filología, Universidad de Santiago de Compostela, Campus Norte. Avda. de

Castelao, s/n. 15782, Santiago de Compostela, A Coruña, Spain 